\title{
School and workplace sarpras influence on the performance of kindergarten teacher
}

\author{
Juliana $\mathbf{S}^{1}$, Yasir Arafat ${ }^{2}$, Syaiful Eddy ${ }^{2}$ \\ ${ }^{1}$ Taman Kanak-kanak Aisyiyah Bustanul Athfal Sukadamai, Indonesia \\ ${ }^{2}$ Universitas PGRI Palembang, Indonesia
}

\begin{tabular}{l} 
Article Info \\
\hline Article history: \\
Received Jul $9^{\text {th }}, 2021$ \\
Revised Aug $15^{\text {th }}, 2021$ \\
Accepted Aug $30^{\text {th }}, 2021$ \\
\hline
\end{tabular}

\section{Keyword:}

Infrastructure

Workplace

Teacher performance

\begin{abstract}
Research aims to understand influence infrastructure to school and workplace on teacher performance. The study was conducted in Plakat Tinggi Musi Banyuasin district.Type this research is quantitative research with the design penetian use design this research expost facto capital.Included in this study was a total all teachers in public primary schools as TK in plakat tinggi district consisting of 50 the teachers. Technique use survey data collection, dokumetasi and observation. Data analysis technique using a technique descriptive analysis kuantittaif, berganda and regression. Results stated that 1) is to influence infrastructure as a teacher tk kecamatan placard; 2) is high environmental influences work on teacher performance kindergarten to high as kecamatan placard; 3) is influence together to infrastructure and workplace tk on teacher performance as Plakat Tinggi kabupaten Musi Banyuasin.
\end{abstract}

(C) 2021 The Authors. Published by IICET.

This is an open access article under the CC BY-NC-SA license

(https://creativecommons.org/licenses/by-nc-sa/4.0

\section{Corresponding Author:}

Juliana S.,

Taman Kanak-kanak Aisyiyah Bustanul Athfal Sukadamai, Indonesia

Email: rafvi.sky18@gmail.com

\section{Introduction}

Early childhood education an educational very fundamental and strategic in the construction of human resources resources people. Hence, wisely it can be said that quality education will produce the quality of quality education them [1]. In the act of number 20 year 2003 on the national education system seventh section article 28 paragraph 3 and 4 there are two the services paud in which are (1) the formal , consisting of kindergarten raudhatul athfal (RA) / Bustanul Athfal (BA) and non-formal, playgroup , daycare, and a unit of paud a kind of. Institutions paud many managed by institutions individuals or groups [2]. Paud that all agencies in indonesia quality can be government institutions has the feasibility assessment quality this authority institutions paud authority held by the national education early childhood and non formal education based on permendikbud no. 52 about the year 2015 paud and pnf chapter article 1 verse 1 . And 8 which is used to national standard for penyeolengaraan paud education (1) the standard development attainment, (2) the standard, (3), standard process (4) standard, teachers and staff (5) standard of infrastructures , (6) standard management, (7) standard financing and (8) standard education the law the Indonesian government .

In 2019 the enactment of a reference to sort out the instruments of units complaince as a prerequisite to the authority and the instrument as an assessment of the performance of accreditation unit for the fulfillment of the quality of learning. The second is a reference inturmen teachers work the quality of teachers is one component is very important in early childhood education in the process, so that they have the roles and responsibilities of a great success of education. Especially early childhood education pre, requiring teachers to 
have in managing it aimed to introduce active learning directly through the small groups, individual, or a large group. Kindergarten teacher should not take over the children, where the teachers must follow the idea, but a boost for children to have these ideas and active learner reviewing own Support as it is very important to encourage the establishment of a relationship experience or knowledge of those they have a child with what is the goddess and Suryana. Philosophically of kindergarten aims to help children in order to develop a variety of potential that they have in accordance with the unique.

For that reason, one of the aspects that most basic in terms of increasing education service quality early childhood is a teacher, because according to input the performance of teachers is the most important thing for the educational. According to Prawirosentono in performance is the work of that can be attained by someone or of a group of people in an organization, in accordance with the authority and responsibility of a bid to improve the organization concerned legally, not unlawful and conformity with the norm and ethics .

Based on act no 20 year 2003 on the national education system article 1 verse 14 stated that early childhood education (PAUD) was an attempt development addressed to children at birth to with six years of age stimuli done through the provision of education for help grow and development of physical and spiritual child has readiness to enter further education. Tk is the efforts to stimulate, guide, after, and provide learning activities abilities and skills that will produce for children in age.

Kindergarten is also the level of education early that can help the development of the baby that began in since birth to six years of age, babies to have the readiness to extend their education to higher degrees. [3] the implementation of paud using the principles of as follows (1) oriented to the needs of a child; (2) learn through play; (3) using an enabling environment; (4) uses various skill life; (5) uses various media educational and source of learning; and ( 6 ) employed the concept of simple and close to children .

The organization of paud should build on certain prinsip-prinsip, that principle should be against children using the media and the concept that can be encouraging a child at the age of who is beginning to education. Function and purpose paud is a component that cannot be separated, because with the function and purpose paud then it would revive and develop education as long as it is considered not that important.Paud function is to provide a stimulus to a child to have readiness to enter further education in a way to build and develop its potential. Hence, on teacher performance is to function and in achieving the cause of education paud. Good any the quality of education in kindergarten be contingent from the performance of TK teachers who establish learning

[4] there are several factors that would improve on teacher performance among others ; salary infrastructure; physical labor and environmental conditions; leadership. These opinions are supported by the research done [5]who stated that they found a positive influence and significant secar together to infrastructure and workplace on teacher performance.

Thus, to achieve a maximum working no factor influence it one. school infrastructure school teacher. is very conducive to workTeachers equipped with complete and adequate infrastructure will perform better than teachers are dilengkapai infrastructure and adequate [3]. And then Suggested that this nations certainly should not be mere fact of the education system but a quality education, one of these is the input from the education facilities. This indicates that a good performance from teachers is strongly influenced by facilities and infrastructures adequate provided by an institution and vice versa inadequate a infrastructure of will also reduce their performance .Facilities and infrastructures supporting, be able to help the teacher of their duties. Facilities is any device equipment, material, and a piece of furniture that directly used in the process education in school [3]. Law. no. 20 year 2003 on the national education system stated that any unit of formal and nonformal education provides fulfill the need infrastructure based on the education and development of physical, potential intellect intellectual, social, emotional, students and psychiatric.

Classifications of the means covering goods discharged or failure use, move are permitted when used, and its relation to the learning process. While infrastructure is any device completeness basic indirectly support the implementation of education process in school .Infrastructure divided into two that which is used direct and not used in learning .Infrastructure directly used covering class, space practices, the library, and space laboratory [5] .

But, in reality, it is schools still experienced a number of problems in developing of educational infrastructure. Kendala-kendala in the development of infrastructures among others are the, the fulfillment of infrastructure of which are not urgent needed school, the number of the of educational infrastructure in supporting learning nothing compared to the number of students and teachers at schools the location and the availability of infrastructure of but not in accordance with their needs school tuition so that means of infrastructures are only kept in the warehouse and increasingly being broken before used to support learning 
activities in school .A problem or this obstacle may be due to the lack of awareness of all components that is in schools about the importance of developing of educational infrastructure exactly. In fact, have not yet been widely tk which able to manage of educational infrastructure exactly. In fact, have not yet been widely tk which able to manage of educational infrastructure exactly. And, one of the easiest indicator measured to know a the school quality or not, can be seen completeness of infrastructure of education in supporting the teaching process in schools .Getting better and better and complete of educational infrastructure that is in a school so will increase satisfaction work had managed to improve kienrja teachers and perceptions of to the quality of schools are also will be getting better.

Other factors that affect the performance of teachers are. working environmentWorking conditions that support is needed is a work environment. comfortable to them A good working environment will depends on them to a better job. anywayThey preferred the physical harmless or convenient.Besides, the majority of like a workplace relatively close [4].

Many of the other problems related to the performance of teachers kindergarten in district placards high where teachers lack of ability in implementing guidance to students who have the problem in a moral that acts like a student to a companion in play, like to lie , commits iniquity.Then on the development as experienced difficulty understand / information, were slow to understand information / explanation and misunderstood the words.In the face of this problem, some teachers are still doing action by spoke directly when there was what relating to moral problems. This suggests that some of the teachers did not understand how the way of executing guidance to students who should have integrated with kindergarten kids learning program , for example pembiasaan training and, playing the role of, modeling, the guidance. The activities must be implemented teachers routinely, and sustainable with a topic that vary in accordance with the problems experienced by children in kindergarten that teachers can know more in the characteristics of the student

Many of the other problems from the observation beginning in some overall kindergarten Plakat Tinggi districtdo not have facilities and infrastructures memamdahi .One of them is in kindergarten Plakat district from the observation by the 25th of january 2020 identified that kindergarten Plakat Tinggi districtdo not have infrastructure of such as a library, and places and facilities play still use material other than of the plastic indicates that facilities or means of infrastructure in kindergarten aba not have a minimum standard facilities play .In addition, lounge facilities parents adjacent to space learn very influence on the learning .Limited means of infrastructure kindergarten such as space office and the playpen inside and outside of judged to be one factor that seriously impact on performance of teachers. Level ketercapaian education infrastructure primary school reached 60,94\% .Level ketercapaian we this low caused by the lack of infrastructures school .

The results of preliminary observations made by the researchers said that most of the kindergarten teacher Plakat Tinggi districtstill have not had a good working environment and infrastructure of schools that still limited assessed by researchers widening opportunities for teacher performance in kindergarten Plakat Tinggi district. Hence, need to do research kuantittaif rests on the process of scientific research to know the answer from the hypothesis while in this research.Thus, the results of preliminary observations conducted by researchers, can be used as an anvil early for researchers to conduct further research with the title of the influence of infrastructure of school and workplace performance against teachers in kindergarten Plakat Tinggi district.

\section{Method}

This research is research quantitative with the design the research uses design this research expost facto capital Sample in this research was the total teachers in public primary schools se kecamatan sekayu the musi banyuasin consisting of 143 the teachers..

Subject to research this all teachers kindergarten in district placards high as 50 teachers and collecting data to research it uses the survey or the questionnaire, documentation, observation, the results of the validation known that the $r$ count all items about $t$; value $r$ table, thus all about in this research considered valid and it is reliable. Pengujuan hypothesis to research it uses multiple linea regression, the model $t$ and feasibility study.

\section{Results and Discussions}

The result of this research stated that performance of teachers has been affected positively by means of infrastructure in school. Facilities and infrastructures completely is give impetus and motivation to teachers in perform the duties in give a lesson to students .Teachers will be easy in developing its potential to create learning an effective and interesting .[6] found that 1 there is the influence of significant motivation work of 
the performance of teachers , 2 is influence significant discipline work of the performance of teachers , and 3) influence significant of the incentives work and discipline work of the performance of teachers

The research shows that workplace arranged have leverage positive on on teacher performance. Workplace climate conducive is perfect fit and support them the education process and teachers. As research of [7] stated that any impact: 1 ) significant schools to culture on teacher performance in public primary schools kecamatan sungai wax; 2 ) any impact to significant a teacher training in public primary schools kecamatan sungai wax any impact; 3 ) significant culture schools and training to on teacher performance together in public primary schools kecamatan sungai wax.

Thus, good working environment will make teachers feel secure , comfortable in do teaching and learning activities that teachers can improve the learning and teaching ability to process or be more attractive and able to accomplish a purpose it desirable. Working environment in schools describe the state of the schools in the school principal teacher relationship, teachers with teachers, with students and teachers .

Results research, backed by elfita zulhaini \& amp; mailani ( 2019 ) who claimed that there was work nonphysical environmental influences on performance islamic education teachers in schools ibubapa sentajo kecamatan singingi kabupaten singingi kuantan singingi the known koefesien $\mathrm{r}$ ( the determination of ( is ) squere 0,791 pengkuadratan of correlation koefesien, or $\mathrm{x} 0,8430,843=0,710649)$. The determination the koefesien $r$ ( the square ) 0,710 meant that they influential performance operating environment on him islamic education teachers.

The research results show that of facilities and infrastructure and workplace teachers performance of teachers a positive influence .The facilities and infrastructures complete will encourage and motivate teachers teaching and learning in doing so teachers more capable of increased its own capacity the teaching and learning activities be more attractive and a maximum of and able to accomplish a purpose of learning which he desired .So is the establishment of the positive work environment in school happens when interwoven a good relationship and harmonious between the head of schools and teachers, teachers with teachers, denagn teachers and education staff, as well as students.

Research in line with research conducted by marliya. [8] with results also shows that 1).Any impact on performance teachers in infrastructure smpn se-kecamatan west prabumulih. The influence on performance teachers in infrastructure smpn se-kecamatan prabumulih 32,6 west of the remaining $\% \% 67,4$ affected by other factors in this research not be variable.2 ).Any impact on performance teachers in operating environment smpn se-kecamatan west Prabumulih .The environmental influences work on performance teachers in smpn prabumulih se-kecamatan west of $43,2 \%$ and the rest $\% 56,8$ affected by other factors in this research not be variable. 3 ).Any impact infrastructure and workplace together on performance teachers in smpn sekecamatan west prabumulih.Big the influence of infrastructure and workplace together on performance teachers in smpn se-kecamatan west prabumulih, of 53,5\% and the rest $\% 46,5$ affected by another factor not included this variables in research.

The results of the research of the [8] stated that infrastructure influences on teacher performance smpn in kecamatan sekayu that can be seen from thitung (2,551); ( ttabel 1,993).The variable influence on the $\mathrm{x} 1$ he is conformed to a line he the $=90,936+0,290 \times 1$. And the contribution to the $\mathrm{x}$ lines he can be seen from the degree of determinasinya 8,4 percent.Workplace influences on teacher performance smpn in kecamatan sekayu that can be seen from thitung $(4,82)$; (tabel 1,993).The variable influence on the $\mathrm{x} 1$ he is conformed to a line he the $=24,255+0,336 \times 1$.And the contribution to the $\mathrm{x}$ lines he can be seen from the degree of determinasinya 24,7 percent. Infrastructures and workplace bersama-sama effect on performance teacher junior high schools in kecamatan sekayu that can be seen from fhitung $=11,514<\mathrm{ftabel}=3,128$ and the magnitude of the influence of variable $\mathrm{x} 1$ and $\mathrm{x} 2$ against $\mathrm{y}$ value is in accordance with the equation a line $\mathrm{y}=$ $60,635+0,160 \times 1+0,356 \times 2$. While the amount of contributions equation $\mathrm{x} 1$ line against $\mathrm{y}$ can be seen from degrees coefficient 24,8 . the determination as much as percent.

\section{Conclusions}

According to the analysis of data and the testing of hypotheses can be taken as follows: conclusion: 1) Significant is the infrastructure of schools to kindergarten teacher performance Plakat Tinggi district .. high. 2) There are significant influence on the performance of workplace Plakat Tinggi district kindergarten teacher. There are significant influence in infrastructure bersama-sama between school and workplace for kindergarten teacher performance Plakat Tinggi district .Big the influence of school infrastructure and workplace for kindergarten teacher performance Plakat Tinggi district district musi banyuasinsecara bersama-sama of 97,4 \% $2,6 \%$ and the rest in the stir in other subjects in this study. 


\section{References}

[1] Khosiah, S., \& Maryani, K. (2020). Pengaruh Gaya Kepemimpinan Demokratis Kepala Sekolah Terhadap Kinerja Guru PAUD. Jurnal Golden Age, 4(01), 20-29.

[2] Efferi, A. (2015). Model Pendidikan Guru Dalam Meningkatkan Mutu Pendidikan. QUALITY, 3(2), 237256.

[3] Barnawi dan Arifin,M. (2014). Kinerja Guru Profesional. Yogyakarta: Ar-Ruzz Media.

[4] Usman, H. (2015). Manajemen (Teori Praktik dan Riset Pendidikan). Jakarta: Bumi Aksara.

[5] Fauziana, D. (2017). Pengaruh sarana prasarana sekolah dan lingkungan kerja terhadap kinerja guru di pondok pesantren al-Islam Joresan Mlarak (Doctoral dissertation, IAIN Ponorogo).

[6] Alhusaini,A.,Kriatiawan,M., \& Eddy, S. (2020).Pengaruh Motivasi Kerja dan Disiplin Kerja Terhadap Kinerja Guru. Jurnal PendidikanTambusai,4(3)2166-2173

[7] Dahlan, M., Arafat, Y., \& Eddy, S. (2020). Pengaruh Budaya Sekolah dan Diklat terhadap Kinerja Guru. Journal of Education Research, 1(3), 218-225.

[8] Angrainy, A., Fitria, H., \& Fitiani, Y. (2020). Pengaruh Sarana Prasarana dan Lingkungan Kerja terhadap Kinerja Guru. Journal of Education Research, 1(2), 154-159.

[9] Selvia, A. (2021). Pengaruh Motivasi dan Disiplin Kerja terhadap Kinerja Guru di Sekolah Menengah Pertama Negeri se Kecamatan Tempuling Kabupaten Indragiri Hilir. Jurnal Pendidikan Tambusai, 5(2), 2633-2637.

[10] Sucitra, D. (2021). Pengaruh Motivasi, Etos Kerja Dan Disiplin Kerja Terhadap Produktivitas Kerja Guru Pada Instansi Pendidikan Madrasah Ibtidaiyah Negeri (MIN) Binjai. Kumpulan Karya Ilmiah Mahasiswa Fakultas Sosial Sains, 2(02). 